Bu makaleye atıfta bulunmak için/To cite this article:

CAN, T. (2021). The Theatre of Steven Berkoff and Sink the Belgrano!. Atatürk Üniversitesi Sosyal Bilimler Enstitüsü Dergisi, 25 (3), 1039-1049.

\title{
The Theatre of Steven Berkoff and Sink the Belgrano!
}

\section{Taner $C A N^{(*)}$}

Abstract: Steven Berkoff is one of the living legends of British theatre. He has spent most of his adult life on stage. He has written, directed and acted in numerous plays. He has also appeared in many well-known movies, such as A Clockwork Orange (1971), Rambo (1985) and Underworld (1985). In spite of his multifaceted international career, little scholarly research has been conducted on Steven Berkoff's art. The aim of this paper is to outline the key characteristics of Berkoff's conception of theatre, usually referred to as Berkovian aesthetic, and present a political reading of his celebrated play, Sink the Belgrano! (1986). The play deals with the Falklands War between England and Argentina, particularly focusing on the events that led to the sinking of the Argentinian Navy light cruiser The General Belgrano by the British nuclear submarine HMS Conqueror. The play also reflects Berkoff's tendency to bring together various experimental dramatic techniques. The present paper firstly highlights the key characteristics of Bekovian aesthetic and then presents a comprehensive analysis of Sink the Belgrano! as one of Berkoff's quintessential plays.

Keywords: War drama, Steven Berkoff, the Falklands War, British drama, political satire

\section{Steven Berkoff Tiyatrosu ve Sink the Belgrano}

Öz: Steven Berkoff, Ingiliz tiyatrosunun yaşayan efsanelerinden biridir. Yaşamının büyük bölümünü sahnede geçiren Berkoff, çok saylda tiyatro oyununda yazarlık, yönetmenlik ve oyunculuk yapmış, A Clockwork Orange (1971), Rambo (1985) ve Underworld (1985) gibi birçok tanınmıs filmde rol almıştır. Çok yönlü uluslararası kariyerine rağmen, Steven Berkoff hakkında az sayıda akademik çalışma bulunmaktadır. Bu makalenin amacı, Berkoff'un genellikle "Berkovian estetiği " olarak adlandırılan tiyatro anlayışının temel özelliklerini aktarmak ve onun Sink the Belgrano! (1986) adlı oyunun siyasi bir okumasinı sunmaktır. 1982 yllinda Ingiltere ile Arjantin arasında meydana gelen Falklands Savașı'nı konu alan oyun, özellikle Margaret Thatcher ve onun savaş kabinesinin aldı ̆̆ tartışmalı bir kararla batırlan Arjantin Donanması'na ait hafif kruvazörü General Belgrano'nun trajik öyküsünü aktarır. Oyun aynı zamanda Berkoff'un çeşitli deneysel dramatik teknikleri bir araya getirme eğiliminin en iyi örneklerinden birini sunar. İki bölümden oluşan bu çalışmada Berkoff'un tiyatro anlayışının başat özellikleri vurguladıktan sonra yazartn en önemli oyunlarından biri olan Sink the Belgrano'nun ayrintil bir incelemesi sunulur. hiciv

Anahtar Kelimeler: Savaş tiyatrosu, Steven Berkoff, Falkland Savaşı, İngiliz tiyatrosu, siyasi

Makale Gelis Tarihi: 30.06 .2021

Makale Kabul Tarihi: 20.09.2021

DOI: $10.53487 /$ ataunisosbil.960484

\footnotetext{
*) Doktor Öğretim Üyesi, TED Üniversitesi Fen Edebiyat Fakültesi İngiliz Dili ve Edebiyatı Bölümü (e-posta: taner.can@tedu.edu.tr) (D) Orcid ID: https://orcid.org/0000-0001-8869-4817

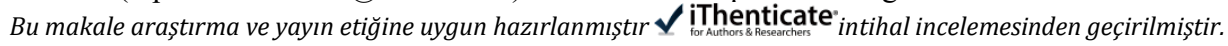




\section{Introduction}

'A life spent on stage' may sound like a cliché phrase that is frequently used to introduce dramatists with distinguished careers, but it simply reflects the reality for the English actor, playwright, and director Steven Berkoff, who has spent most of his adult life on stage. Berkoff went on stage for the first time in a minor role in Arnold Wesker's The Kitchen in 1961, and he has never stepped down since then. He has written, directed and acted in numerous plays. He also appeared in many well-known movies, such as $A$ Clockwork Orange (1971), Rambo (1985) and Underworld (1985). It seems that Berkoff will not retire soon despite his advanced age. He last appeared in a 2021 film, Creation Stories. In spite of his multifaceted international career, little scholarly research has been conducted on Steven Berkoff's art. Except for his autobiographical works Free Associations (1996), The Theatre of Steven Berkoff (1992) and Tales from an Actor's Life (2020), there are not any comprehensive studies on this legendary figure of British theatre. The aim of this paper is to outline the key characteristics of Berkoff's conception of theatre, usually referred to as Berkovian aesthetic, and present a political reading of his celebrated play, Sink the Belgrano! (1986). The play deals with the Falklands War between England and Argentina, particularly focusing on the events that led to the sinking of the Argentinian Navy light cruiser The General Belgrano by the British nuclear submarine HMS Conqueror. Premiered in September 1986 in London, Sink the Belgrano, as Berkoff puts it, is a satirical rendition of Margaret Thatcher's policies that show "an abnormal disregard for human life and values, plus an overwhelming and religious belief in the sanctity of the marketplace" (Berkoff, 1987: 145). Although Thatcher and her war cabinet are the immediate targets of Berkoff's satirical wit, political criticism directed against the role of the media and international organisations, such as the United Nations in wartime makes the play a bold and strong anti-war statement. The play also reflects Berkoff's tendency to bring together various experimental dramatic techniques. As such, Sink the Belgrano not only rewrites the official account of the Falklands War from a critical perspective, but it also offers the quintessence of Berkovian aesthetic.

\section{Steven Berkoff and the Berkovian Aesthetic}

Steven Berkoff was born in 1937, in Stepney, London. He describes himself as a child as "a shy, withdrawn daydreamer who took pleasure in isolation" (Cross, 2004: 21). His childhood and early teenage years were plagued with family problems. His broken relationship with his family and his reserved personality arouse in him an inclination towards arts. "At the age of twelve," Berkoff notes, "I had great pride in myself and what I felt to be my goals -- which were to be famous as either 'a writer,' 'a priest' or 'film star"' (Berkoff, 1996: 8). In an interview, he states that he considers theatre to be a refuge for loners like himself: "I think a lot of actors and people who go into the theatre are lonely people. I think, first of all, they're lonely from their family. Something about them is a bit different. They are isolated, have different sensibilities, they can't communicate within their family and then they decided to enter the theatre. Theatre is a big family" (Rosen, 2000). Berkoff's troubled early life may account for his devotion to theatre and the reason why isolation became a leitmotif in his plays, such as East (1975), Greek 
(1980) and West (1983). There is yet another important source of inspiration that had an overarching influence on Berkoff's life and his conception of theatre. At the age of 18 , Berkoff moved to Germany, where he read a book that changed his life: Franz Kafka's Metamorphosis. Even when he read it for the first time, he felt that Gregor Samsa would stay with him for the rest of his life. He would later stage an adaptation of the novel as well. "I read Metamorphosis, " Berkoff writes, "for the first time there in Germany and connected it with Germany, with the environment, the atmosphere and my state of mind. I thought it was the most marvellous story and I could at last identify with something. The beetle" (Berkoff, 1996: 168). When Berkoff returned to England in 1956, John Osborne's Look Back in Anger was sweeping British theatre. Osborne's Jimmy Porter, however, did not have any significant impact on Berkoff's idea of theatre at all since he was still under the influence of Kafka's Metamorphosis, which challenged the limits of conventional literary practices with its magical realist style. Look Back in Anger, Berkoff writes, "had not had the slightest effect on me, as I remember... This Look Back in Anger seemed terribly conventional. Theatre in my mind was something to do with magic, music hall, Harry Houdini and tightrope walkers. Ideas belonged in books" (Berkoff, 1996: 212). It is clear that Berkoff strived, even in the early stages of his career, to create a visual show without much concern about realism, or verisimilitude in theatre. However, he could not find a theatre company where he could develop his dramatic theories. For Berkoff, the productions of the mainstream theatres looked too traditional and nonfunctional. He, nevertheless, went on acting in different companies to earn his living. Reminiscing those days, Berkoff writes, "[ $\mathrm{t}]$ he theatre began to tire me with its routine and the loneliness since there was no real fraternization, no change of personalities... and no demanding work for me to do. I was rotting away with a good salary" (Berkoff, 1996: 229).

His growing discontent with the traditional acting style led Berkoff to found his own theatre company, namely The London Theatre Group, in 1968. He developed his own acting style there, which was later to be named after him by the critics: "Berkovian aesthetic." In an interview with Craig Rosen dated 6 June 1998, Berkoff points out that there are two important characteristics of his theatre. Firstly, it demands a break with the conventions of the mainstream theatre. He regards his theatre as one of the possible ways of acting, not necessarily a better one. Nor does he reject any of the previous artistic traditions in theatre except for naturalism, which he considers "fairly dead" (Rosen, 2000). In developing his own theory of drama, Berkoff drew heavily from Brecht, Artaud and Barrault. Few or no stage props, unrealistic use of make-up and an extensive use of mime and dancing are the defining features of Berkovian aesthetics (Berkoff, 1992: 1014). As Craig Rosen notes, Metamorphosis, Berkoff's first adaptation play, is an epitome of Berkoff's eclectic, experimental staging method, known as Berkovian aesthetic:

Metamorphosis combined elements of Brechtian Epic Theatre by using actors to purposefully represent characters rather than become them; Antonin Artaud's Theatre of Cruelty by breaking from traditional theatre texts and asking the actors to bare their inner thoughts as 
if they were human-sacrifices to create ritualistic theatre; Jean-Louis Barrault's "total-theatre" by using all possible means to uncover the meaning -- conscious or otherwise - of the play; and Jacques Le Coq's theories of mime, movement, masks, and ensemble, by using the performers to create the environment. (Rosen, 2000).

The second important characteristic of Berkoff's theatre is rooted in the immense liberty he gives to actors. His is an actor-centred theatre. "I don't like to be directed by directors," asserts Berkoff, "because only an actor knows" (Rosen, 2000). Diversity, innovation and experimentalism are what Berkoff most appreciates in a performance. Hence, for him, actors should be completely free on stage so that they can deliver their best performances. He mentions that he has had problems with the actors from mainstream theatre companies, such as the National Theatre and Royal Shakespeare Company: “[ $t]$ hose kind of actors are appalling and they don't fit in. They're... just doing the lines -- not living through the lines; their body being separate from their heads. So, they say their lines, and try to make sense of it, but very often there's little else going on" (Rosen, 2000). In contrast, for Berkoff, "[a]cting is for me the closest metaphor to human sacrifice on the stage... By describing the accident, the witness becomes the accident; he is there reliving it" (Berkoff, 1978: 11). As the remainder of the article attempts to demonstrate, Berkoff's experimentalism never prevented him from exploring socio-political problems of the time. On the contrary, he utilised his unconventional stage designs and acting methods to bring these problems to the public attention.

\section{A Political Reading of Berkoff's Sink the Belgrano!}

The Falkland Islands, situated in the South Atlantic Ocean, have been a dispute of territorial sovereignty between England and Argentina since the $19^{\text {th }}$ century. The centuries-long dispute culminated into a war on April 8, 1982 with Argentina's invasion of the islands and England's armed retaliation against the invasion. The Falklands War lasted seventy-four days and ended with Argentina's surrender on June 14, 1982, leaving the islands to British control. In total, it claimed the lives of 255 British and 649 Argentinian soldiers (Young, 1991: 276-77). The Falklands War was immediately transformed into a national myth in the popular imagination by the Thatcher government to help recover its dwindling popularity. In One of $U_{s}$, a comprehensive political biography on Margaret Thatcher, Hugo Young notes, "[i]n the political history of Margaret Thatcher the Falklands War played the part of an unqualified triumph. Because it ended in a great victory [...] it made her position unassailable, both in the party and in the country. It guaranteed her what was not previously assured: a second term in her office" (Young, 1991: 258). In response to the official Falklands myth, there were also dissident voices aimed to show how an avoidable territorial dispute was culminated into a war and exploited for political ends. These anti-war views gave rise to a large body of narratives, which David Monaghan calls 'counter-mythic works,' including cartoons, stage plays, documentaries, soldiers' memoirs, novels, films and stage plays. Monaghan notes that these courter-mythic works "reframe the official Falklands myth as a network of lies constructed by a self-interested politician willing to distort language and history 
in order to advance her own political agenda" (Monaghan, 1998: xiii). In other words, an ideological battle ensued the Falklands War in which artists sought to rewrite the official account of the war to capture the controversies and ambiguities behind the political scheme that led to a bloody war and cost hundreds of lives.

Steven Berkoff's Sink the Belgrano belongs to this line of counter-mythic literature about the Falklands War, along with some other stage plays, such as Falkland Sound by Louise Page, Our Boys by Jonathan Lewis and Tumbledown by Charles Wood. Berkoff centres his political satire on a key incident in the Falklands War: the sinking of The General Belgrano, an Argentinian Navy light cruiser by the British submarine, The Conqueror. In the introduction to the volume, which contains the play, Berkoff explains why he chose to focus specifically on the events leading to the sinking of the Belgrano in his play: "It is apparent to everyone that the sinking of the Belgrano was a very dubious affair, [...] a typical product of that muddled and opportunist thinking. The irony is that brave Britons and Argentinians lost their lives needlessly" (Berkoff, 1987: 1). Berkoff's play differs from its counterparts with its juvenile type of stinging political criticism shaped by a vulgar language and uncompromising anti-militarist stance. Berkoff adopts a simple and straightforward style in the play, which renders his political satire too obvious to overlook. The first and perhaps the most explicit attack on the Thatcher government is Berkoff's vulgarisation of the names of the politicians in the cabinet. In addition to the opportunist politicians, Berkoff also satirises the United Nations' failure to prevent wars and the media's manipulation of public opinion. The table below helps identify the historical figures and institutions satirised in the play:

\begin{tabular}{|l|l|l|}
\hline Character & Historical Personage & Title \\
\hline Maggot Scratcher & Margaret Thatcher & Prime Minister \\
\hline Pimp & Francis Pym & Foreign Secretary \\
\hline Nit & John Nott & Defence Secretary \\
\hline Woody & Rear Admiral Sandy Woodward & Operational Commander \\
\hline Whitehall & Willy Whitelaw & Deputy and Trusted Advisor \\
\hline The UNO & The United Nations & \\
\hline
\end{tabular}

The plotline follows the course of the war chronologically, yet with a satirical underpinning that aims to shows us that the official account of the Falklands War is quite different from what actually happened. According to David Monaghan, Sink the Belgrano turns the official account of the war on its head by presenting inverted images of politicians as well as the nationalist discourse they used. "[H]eroism," asserts Monaghan, "is reflected as villainy, good as evil, moral purpose as dishonesty, the spiritual either as the demonic or the material, altruism as crass self-interest, the more than human as the subhuman, mythic archetype as cartoon grotesque, and high diction as low vernacular" (Monaghan, 1998: 61). The most obvious element of Berkovian aesthetic in the play seems to be the unconventional stage design with three separate divisions: "Upstage, on a rostrum running left and right, was the political area with desk, and behind it a large screen for projecting images. Downstage, on the main playing area, 
was drawn the outline of a huge submarine. [...] Stage left was a pub area which represented the "voice of England"' (Berkoff, 1987: 143). As the stage design suggests, Berkoff wants the audience to see the war from alternative perspectives and question the ideological discourse of nationalism exploited by the government and the media to create a national myth out of the bloodshed and suffering inflicted by the war. The stage design also helps create an alienation effect (Verfremdung) as it leads the audience to watch the play from a critical distance by constantly reminding them the artificiality of the theatrical performance.

Another dramatic device used by Berkoff to reinforce the message of the play is the chorus. As a characteristic of the epic theatre, the chorus has a functional role in the play. It not only clarifies the action by introducing the organisations and sides involved in the war, but also voices Berkoff's attitude towards Margaret Thatcher and her cabinet. In other words, the chorus becomes the playwright's mouthpiece, caricaturing Margaret Thatcher and her perceived political stature. The play opens with the address of the chorus that praises the expansionist past of England and her triumph over other nations in a sarcastic tone. However, this mighty nation has lost much of its glory recently and become vulnerable to foreign threats: "Worn out with strikes and social strife / Numb with queues of unemployed that add / Their groaning weight to the nation's back" (Berkoff, 1987: 3). Following the chorus' short introduction, Foreign Secretary, Francis Pym, whose name is vulgarised as "Pimp" in the play, appears on the stage and calls on the Prime Minister Margaret Thatcher (Maggot Scratcher) to take action against Argentina's invasion of the Falklands. Maggot's immediate reaction is to take military action and start a war between the two countries: "Maggot: ... Call out the Fleet, get planes / And tanks, I love to have a crisis on my hands" (Berkoff, 1987: 4). Pimp calms her down, suggesting that they should be more political and get the UNO behind them first. That is what exactly the Thatcher government did. England brought the matter before the UN Security Council on 3 April 1982, demanding the immediate cessation of hostilities and removal of Argentinian forces (Freedman, 2005: 33-39). The heated discussion between the prime minister and the foreign secretary over what to do against Argentina's invasion ends with the former's question: "By the way Pimp.... Where is the Falklands" (Berkoff, 1987: 5). Maggot repeats the same question at the end of the introductory part of the play:

\author{
Maggot: we need a war \\ Establish once again our might and strength \\ Shake our old mane, out fly the moths \\ Oh God, I start to feel myself again \\ Now where is this damn Falkland Isle? (Berkoff, 1987: 7)
}

Margaret Thatcher is at the centre of Berkoff's political satire since she, as David Monaghan points out, is both the "maker and hero of the Falklands myth" (Monaghan, 1998: 39). By portraying Thatcher as a warmonger with complete ignorance, Berkoff shows that politicians are not true patriots as they claim to be, but a group of opportunists 
who would do anything, even start a war for their self-interests. Satire does not solely reside in caricature of the characters, but it also extends to other aspects of the Falklands myth, particularly the chivalric language used by the Thatcher cabinet and the British press to describe the military activities during the Falklands crisis and the ensuing war. Stylistically, the simple crude language used in the play subverts this chivalric rhetoric and appropriately reflects the baseness of the politicians and their deeds.

The rest of the play continues in a similar vein and spotlights the critical moments in the course of the war. With each scene, Berkoff provides further rationale for looking at the war and all the involved parties in a different light, as opposed to the official account created by the mass media. The discrepancies between the official and the alternative narratives of the war invite the audience to reconsider what they know about the Falkland policies. For instance, Berkoff's Maggot makes it clear that the Falkland Islands (a group of thinly populated rocky islands 8,000 miles away from England) do not mean much to England except for their geopolitical significance:

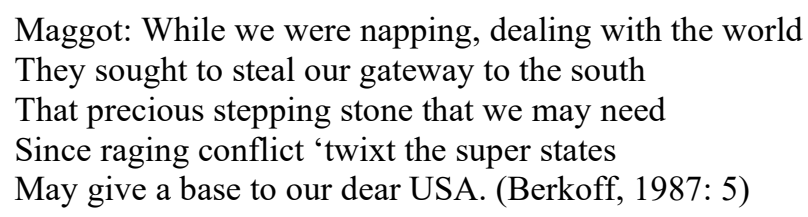

During the Falklands crisis, the Thatcher government, however, deployed a completely different political discourse to justify the military intervention. Using the media power, they promoted an image of Falklanders as helpless victims captivated by a powerful aggressor, desperately seeking help. The role assigned to England in this political scheme was, of course, none other than that of a saviour state. In other words, according to the official version of the war, England's policies about the islands are completely driven by altruistic motivations. The politicians took every opportunity to underscore the humanitarian and altruistic motivations behind England's military intervention. For example, in an interview with Time magazine, Thatcher claimed that the Falklanders were "under [the] heel of the savage Argentinian tyrant through a totally unprovoked act of aggression, now look to the British hero to do his duty by stand[ing] up for them" (Monaghan, 1998: 14). The hypocrisy of the Thatcher government is laid bare again with the appearance of a group of Falklands farmers in the play who complain about the British colonialism, which exploits their labour and resources of the island through the Falkland Islands Company (FIC):

Farmer I: oh toil, oh strife, oh bleeding graft Is this the life that I daily spout?

Four sixty quid a week they bleed our veins

And us poor farmers slave for next to nought

We live in this pisspot, this dreary rock

Where no one has invested, not a jot... 
The profits never go to thee or me,

Where then? The bloody bleedin' FIC. (Berkoff, 1987: 5-6)

Throughout the play, Berkoff puts down his satirical pen that spares none only when depicting Argentina and its political leader. As opposed to the image of the evil enemy promoted by the British political leaders, Berkoff portrays Argentina as a benevolent state, advocating universal values, such as human rights and peace. That is why the islanders turn to Argentina for help when they are seriously ill or injured: "Farmer 2: When we are ill or hurt we fly / To Argy land where Argy hands / Repair our broken bodies" (Berkoff, 1987: 6). Likewise, the president of Argentina is the only political figure that appears on stage without vulgarisation of his name or title; he is simply referred to as 'President of Argentina.' He appears only once in the play and delivers a serious soliloquy, which reads like a concise parliamentary address. He defends Argentina's legitimate rights on the Falkland Islands with concrete historical and political arguments without slipping into an empty jingoistic discourse used by the Thatcher cabinet.

Having, thus, voiced the legitimacy of Argentina's claims that did not receive any attention in the British media, Berkoff moves on the most critical and controversial moment in the course of the Falklands War, Thatcher's political decision to sink of the Belgrano. In this final part, the satirical tone shifts into a sombre, tragic tone with the introduction of sailors. Berkoff encourages readers and spectators to view sailors in a neutral manner, leaving their own national and patriotic feelings aside. In the play, the sailors are represented as the victims of the war rather than its perpetrators. This antimilitarist tone can also be seen in Berkoff's production notes of the play regarding the sailors' costumes: "[t]he sailors wore tracksuits throughout which was a simple neutral uniform" (Berkoff, 1987: 142). Like the farmers in the play, the sailors do not have specific names, which renders making them anonymous voices against the war and selfseeking politicians. It is not a coincidence that Berkoff delivers the strongest attack at Margaret Thatcher's political stature through one of the sailors who compares her jingoistic political discourse to that of Adolph Hitler's:

Sailor I: Whenever hard truth won't go down

We grease the way with subtle quotes,

Self-determination, paramount, law and order

All that crap. Old Adolf smashed Slovakia

To protect his German hordes

Sudetenland must have, he said,

Self-determination for those Nazi bores. (Berkoff, 1987: 36)

To darken the tragic tone of the play, Berkoff also integrates into the play one of the most common form of war narratives: letters written by combatant soldiers. Various sailors read out their letters in the play. The feelings and thoughts expressed in these letters show that soldiers are innocent young men rather than gallant warriors with aspirations to 
become heroes. They write about their daily routine on the warship and complain about homesickness. Viewed in entirety, the letters can be seen as anti-war propaganda embedded in the play. One sailor, for instance, writes, "Dear Mum, I can tell you I'm scared / Don't know what we're facing down here / It's so quiet beneath the surface and still" (Berkoff, 1987: 33). Another confesses it to his girlfriend that he does not want to fight: "Dear Judy, I don't want to kill / In fact of war I've had enough" (Berkoff, 1987: 33). In this final section of the play, Berkoff employs his divided stage design to juxtapose the politicians and the soldiers. While the innocent soldiers dream of going home downstage, Maggot Scratcher and her war cabinet hold a meeting to discuss their ruthless war policies upstage. As the submarine The Conqueror is sailing to the Falklands with her innocent crew, the Iron Lady begins the process of her cunning and decisive foreign policies, which she explains with the metaphor of "Spanish omelette" in the play. With this metaphor of total warfare, Maggot makes it clear that she will keep the Falklands whatever the price may be. For this, she firstly replaces Foreign Secretary John Biffen with Francis Pym. Thatcher makes this change because John Biffen's pacifist policies do not fit in with her own militarist plans. She appoints Francis Pym as the new Foreign Secretary, whom Thatcher, in her The Downing Street Years, praises for his political qualities, "Francis is in many ways quintessential old style Tory, a country gentleman and a soldier, a good tactician... He is a proud pragmatist and enemy of ideology, the sort of man whom people used to say that he would be 'just right in a crisis"” (Thatcher, 1993: 187). The second step of Maggot's plot of Spanish omelette is to take control of the British press to gain public support. At this point, the chorus draws attention to the crucial role of media in manipulating the public opinion.

Chorus: Around the land, in every pub,

In every dining room and lounge

The voice of England can be heard

Discussing the Falklands with angry sounds

You'd never believe until last week

They didn't know Falklands from Leigh-on-Sea. (Berkoff, 1987: 23)

Here, by depicting a part of a debate on TV, Berkoff humorously shows how Thatcher and her cabinet easily gained public support with populist policies, such as banning Argentinian national football team from entering The World Cup. Having thus gained the public support through the media, Maggot Scratcher moves on to the last and the most problematic part of her Falklands policy. She charges Pimp to follow a shuttle diplomacy in the US. However, the sole aim of this diplomatic manoeuvre is to win the necessary time for The Conqueror to reach the Falklands, rather than reaching a peaceful solution. With all the diplomatic bridges and peaceful solutions discarded, Maggot waits for the right moment to attack the Argentinean ships. However, none of them trespass into the total exclusion zone. Moreover, English task force was equipped with high frequency transceiver system (Marconi AD 470), which enabled them to detect the movements of Argentine vessels, distinguishing between those ships that posed a threat 
to the British forces and those that did not. What is important for Maggot, however, is to sink an Argentine ship to provoke chauvinist English patriotism. She is sure that such a move will guarantee her victory in the upcoming elections and thus, she orders The Conqueror to attack and sink the Belgrano. It may seem like a simple military manoeuvre to destroy the enemy, but as Berkoff reminds us, modern warfare is reliant on a complex network of power and finance. As the Foreign Secretary Pimp confesses earlier in the play that it is England that sells all the weapons to Argentina:

Pimp: We sell death weapons to those who

Pay. Who cares who they kill, it's their war, We only manufacture death...

We made a fortune

Selling death all around the world

Is it my fault that now by chance

A bloody boomerang's been hurled? (Berkoff, 1987: 14)

Therefore, at the end of the play it becomes clear that the Falklands War is altogether an English design and there are no winners except the corrupt politicians and warmongers. To emphasise this tragic fact, Berkoff ends the play with the words of an innocent sailor, along with Margaret Thatcher's historical assertion projected on the screen with the blackout:

Sailor: somebody threw the first stone

When the Belgrano was going home.

(On screen the following image: 'I would do it again'

... Margaret Thatcher. Blackout.) (Berkoff, 1987: 38)

Following the Falklands War in 1982, Margaret Thatcher became the most popular prime minister in the opinion polls, and subsequently she was re-elected as the prime minister (Young, 1991: 280.). It is true that her Falklands policies were successful, but, as Berkoff indicates in the play, her success story began where the essential humanitarian values were overtaken by fear, anger and aggression.

\section{Conclusion}

In Sink the Belgrano! Steven Berkoff brings together his satirical wit and his eclectic dramatic style to reveal how a minor territorial conflict that could have been solved peacefully through diplomacy was culminated into a war for political ends. Through caricature of political figures and use of vulgar language, Berkoff attacks the official myth of the Falklands War and subverts the chivalric discourse exploited by the politicians and the media. Berkoff's innovative style, such as the chorus and unconventional stage design, lead the audience to view the events in the play from a critical perspective. At the end of the play, it becomes clear that the official account of the Falklands War is nothing more than a dirty political propaganda that cost the lives of 
hundreds of innocent young sailors. By the same token, the Falklands heroine Margaret Thatcher is stripped of her public image as an honourable national leader and turns into an abominable figure. Although the play was inspired by a specific incident in British history, the political message it offers can be translated to a number of different contexts in which deceitful and self-interested politicians prioritise their own careers over human life. Given the universality of its message and experimental dramatic style, Sink the Belgrano! can therefore be regarded as a quintessential example of 'Berkovian aesthetic' with its insights into the playwright's dramatic style and his political stance.

\section{References}

Berkoff, S. (1978). “Three theatre manifestos.” Gambit. Vol. 8 (32), 7-21.

Berkoff, S. (1987). Sink the Belgrano. Faber and Faber.

Berkoff, S. (1992). Theatre of Steven Berkoff. Methuen Drama.

Berkoff, S. (1996). Free association: An autobiography. Faber and Faber.

Cross, R. (2004). Steven Berkoff and the theatre of self-performance. Manchester University Press.

Freedman, L. (2005). The official history of the Falklands campaign: Vol. II war and diplomacy. Routledge.

Monaghan, D. (1998). The Falklands War: myth and countermyth. Macmillan.

Rosen, C. (2000). Creating the "Berkovian" aesthetic: An analysis of Steven Berkoff's performance style. http://www.iainfisher.com/berkoff/berkoff-dissertationaesthetic.html

Thatcher, M. (1993). Downing Street years. Harper Collins.

Young, H. (1991). One of us. Macmillan. 